\title{
ACTUALIZATION OF INTERTEXTUALITY THROUH HISTORICAL SENSE IN T. S. ELIOT'S METATEXT
}

\section{Statkevych L. P.}

\section{INTRODUCTION}

Tomas Stern Eliot was a consistent spokesman of tradition in his multidimensional art (poet, cultural critic and literary theorist). He was one of the first who understood its relevance and necessity for early twentieth-century art. Eliot was not a prolific poet, but each piece of his early poetry is an attempt to imitate, develop, and thus preserve the best examples of secular art experience of humankind. Synthesis and reflection of the literary tradition in Eliot's early works is conditioned by his desire to renew the literary past, enrich it with new semantic nuances and comprehend it in his own metatext, and, repeatedly declared in the cultural essays, strengthen the connection of the times, preserve and develop the tradition in creating the elitist art. Eliot's poetic and philosophical worldview was formed at Harvard, Oxford and Sorbonne under the influence of lecture courses by reputable thinkers and philologists of America and Europe. The concept of creative individuality, based on the idea of literary tradition, is dominant in the poetry of Eliot.

Eliot's literary and aesthetic reflection is a dynamic phenomenon. Quite logically, it is transformed into intertextuality - a dominant feature of his poetics.

The poet thus strengthens the connection of the times and enriches the national cosmopolitan culture by the variant images of the world. By engaging in dialogue with his predecessors, usually the classics who form the poetic canon he created, Eliot preserves and develops a cultural tradition that, in his view, was an important task of the poet. Eliot's poetic work has become an organic part of the Neoclassicism of the last century, consciously oriented to tradition as a philosophical and aesthetically ideological phenomenon. It is the poet's desire to comprehend the literary past, to refresh it and enrich by other semantic nuances in his own metatext. Eliot was recognized as an elitist poet of the last century. Eliot's undoubted merit in the poetic art of the first half of the XX century is that he understood the literary process as a qualitatively new cultural stage and understood the need to preserve 
tradition in a difficult and contradictory period of Avant-gardism. For example, in the preface to the collection of the essay "The Sacred Wood" (1920), Eliot suggested not to regard literature as a closed system of works in its epoch, but as a cultural and aesthetic value that belongs to all eras. It is the ability to rethink, using in his own works diverse material belonging to different cultural and historical epochs, that became the basis of his creative innovation. In his work, Eliot not only satisfied the sense of tradition and strengthened the connection of the epochs, but also developed the poetics of coupling, the basis of which was "the creation of new unities" (T. S. Eliot) and "the combination of the incompatible" (W. Scaff).

\section{Intertextuality in Modern Philological Discours}

Since its first coinage by Bulgarian philosopher and poststructuralist Julia Kristieva in 1966, the term "intertextuality" has come to grasp an unending growing interest in modern philological discourse. The number of studies on this phenomenon continues to escalate, among the reasons is its interdisciplinary emphasis and its postmodern character. However, it has been adjusted and operated oftentimes that it has accumulated a wide range of meanings which makes it necessary to start this article by illuminating the distinctive meanings attached to this term with special focus on its use in modern philological discourse. A number of its foremost theorists promote a diversity of meanings and methods of text decoding.

The term is originally connected with literature of Modernism and Post-modernism. The phenomenon of intertextuality is clarified as dialogical communications between the text and previous texts as well as the forthcoming text generation. Intertextuality, therefore, can be broadly defined as the modeling of texts' meaning by the meaning of another text. Every literary text is not an isolated work of art. The writer consciously and unconsciously carries into the text elements from other texts which he absorbed and transformed and which unavoidably participate in the creation of his own text. This equally applies to the reader who never comes clean to the text and whose cultural enlightenment and reading experience also take part in shaping what meanings he comprehends behind the text. This means that any literary text is "a sort of intervention in a cultural system" since the concept of intertextuality doesn't apply to literary works only but also to any "cultural sign system” or mode of signification (image, film, 
musical composition <...> etc.) Meaning and intelligibility in both text and discourse depend on a network of previous and contemporaneous texts and discourses. The very term "intertextuality" is derived from the Latin word "intertexto" which means "to intermingle or weave together" 1 .

Julia Kristieva rejected the traditional definitions of "originality" and "literary authorship". She grounded her theory of "the three-dimensional textual spaces". According to this opinion, a text could be analyzed in terms of two axes: a horizontal one connecting the author and the reader, and a vertical one connecting the text with the previous texts. According to this conception, a text's meaning is not immovable but in a state of continuous modification, and every reading of it is a new reading. The intertextual view of literary meaning is also adopted by Roland Barthes who declared in 1968 the "death of the author" and the "birth of the reader". This suggests that neither the writer nor the reader need always to be conscious of this process of textual dialogue, a fact which distinguishes "intertextual" studies in an important sense from "influence studies" where the emphasis is on the factual evidence of influence, sources, and deliberate imitation.

Gerard Genette coined the term "transtextuality" as a more inclusive one than Kristieva's "intertextuality”. Under this term, he lists five types or "sources" of interdependence among literary texts, which could be summed up as follows:

1) intertextuality: under this Genette includes quotation, allusion and plagiarism;

2) paratextuality: titles, headings, prefaces, epigraphs (the concern of this study), dedications, <..> etc. Genette calls such elements "paratexts";

3) architextuality: by this term he means the classification of a literary text within a specific genre or established tradition;

4) metatextuality: by this he means explicit or implicit comments of one text on another;

5) hypotextuality or hypertextuality: this is in fact so similar to the fourth that the two almost seem identical. Genette defines it as "the relation between a text and a preceding hypotext, a work or genre which it transforms, modifies, elaborates on, or extends". Here he lists parody, spoof, sequel and translation.

1 Graham Allen, “Intertextuality” in The Literary Encyclopedia, http://www.paulj.myzen.co.uk/ blog/teaching/reinventions/files/2009/07/Allen-Intertextuality.pdf Date of access at 27/8/2019. 
Barthes emphasized on a key role of language; hence unwinding further Saussure's saying that language is a system which pre-exists its speaker. The entire depth of context, therefore, is realized only in the moment of its reading. That is why Barthes appointed that the reader is the only decoder of the text's meaning. The traditional notion of the author's "intention" is totally condemned by modern post-structuralists and deconsructionalists who deeply believe that language is greater than its users, and an author, therefore, can transfer the meanings he is not aware of or which he does not have in mind to convey. Therefore, these associations in the process of co-creation are never unchangeable or fully knowable. The process of perception of a text involves correlation of two dimensions in the mind of the reader: the plan of the text-receiver and the plan of the precedent text. The success of such a process depends on the reader's competence, i.e. his proficiency in a precondition and sophistication, which in this case is considered as the treasury of precedent texts and the rules for their understanding. The better the reader is familiar with the relevant precedent texts, the more elements of semantics, linguistic and stylistic organization of the receiver's text will be comprehended in connection with similar elements of these precedent texts and the more comprehensively the process of text comprehension will happen.

However, the perception of the text is not limited to the formation of the plan of the text-receiver and the level of a precedent text in the mind of the reader. As a result of the perception of the text that implements the category of intertextuality, the reader builds up the third level, the result of the interaction of the first two ones, which is characterised by a unique meaning different from the meanings of the first and the second levels and which depends on the peculiarities of individual perception.

Intertextuality as a conscious literary or critical strategy applied to the formation of the work can be traced back to the works of T. S. Eliot and James Joyce especially in "The Waste Land" (1922) and "Ulysses" (1922). In fact, literature is a space where multiple voices work upon one another. And therefore, there is no possibility of a single, coherent unit. A single voice is made up of multiple voices of the whole tradition. In this key, I want to make mention of one of the most remarkable T. S. Eliot's article "Tradition and the Individual Talent". It was first published in 1919 in the September and December issues of the literary magazine “The Egoist". T. S. Eliot's reformulation of the idea of literary tradition has been one of the key critical concepts of the twentieth century. "Tradition and the Individual Talent" (1919) certifies Eliot protecting 
the role of tradition in helping new writers to become modern. This is one of the central paradoxes of Eliot's critical writings - indeed, of much Modernism - that in order to move forward he often looks at the past, even more directly and more pointedly than previous poets did.

He insisted that every poet who wants to be modern should develop a historical sense. "This historical sense, which is a sense of the timeless as well as of the temporal and of the timeless and the temporal together, is what makes a writer traditional. And it is at the same time what makes a writer most acutely conscious of his place in time, of his contemporaneity". In short, knowledge of writers of the past makes contemporary writers both part of that tradition and part of the contemporary scene. Eliot's own poetry, for instance, is simultaneously in the tradition of Homer and Dante and the work of a modern poet, and it is because of his debt to Homer and Dante that he is both modern and traditional. If this sounds like a paradox, consider how Shakespeare is often considered both a 'timeless' poet ('Not of an age, but for all time', as his friend Ben Jonson said) whose work is constantly being reinvented, but is also understood in the context of Elizabethan and Jacobean social and political outlook. Similarly, in using Dante in his own poetry, Eliot at once makes Dante "modern" and contemporary, and himself - by association - part of the wider poetic tradition.

The „historical sense ${ }^{e e}$ helps developing a literary tradition. He further writes: "no poet, no artist of any art, has his complete meaning alone. His significance, his appreciation is the appreciation of his relation to the dead poets and artists".

Eliot's concept of tradition foregrounds how important older writers are to contemporary writers: Homer and Dante are Eliot's contemporaries because they inform his work as much as those alive in the twentieth century do. James Joyce looked back to ancient Greek myth (the story of Odysseus) for his novel set in modern Dublin, Ulysses (1922). Ezra Pound often looked back to the troubadours and poets of the Middle Ages.

\section{The Cultural Context of Eliot's Poetic Strategy Formation}

In this article, we do not aim to reconstruct the biographical facts of Eliot's life, which are quite widely represented by similar research in Western Eliotology: Lindell Gordon's “T. S. Eliot. Unfinished Life”, by Peter Ackroyd, 2000, “T. S. Eliot: His Life”, 1984, Thomas Stanley Mathews "Big Tom. Notes on T. S. Eliot's Personality”, 1974, etc. We confine ourselves only to the most prominent of the formation of philosophical 
and poetic Eliot's philosophical and poetic worldview with the scientific concepts of eminent scientists and thinkers of America and Europe.

There is no unanimity among Eliotologists about the periodization of the poet's work. Sometimes it is divided into two periods: 1 ) before the adoption of Catholicism; 2) the period of Catholicism.

I consider the division into three periods more correct in terms of modeling the poetic picture of the world and forming the poet's personal worldview:

- "The Period of Denial" - a collection of poems "Prufrock and Other Observations”, 1917, “I Ask You” (“Ara Vos Prec”, 1919), first published in the United States in 1920 as "Poems";

- "Search period" - the poem "The Waste Land", (1922) and “The Hollow Men”, (1925);

- "Catholicism” - poems “Ash Wednesday” (1930), "Four Quarters” (1935-1942), cycle of poems “Ariel” (“Ariel Poems”), unfinished poems “Sweeneey Agonist” (1926), “Coriolan”, “The Rock” (1934), "Murder in the Cathedral” (1935), "The Family Reunion” (1939), "The Cocktail Party" (1950), “The Confidential Clerk" (1954), and "The Exalted Statesman The Elder Statesman”, (1959) ${ }^{2}$.

The proposed periodization of Eliot's poetic creativity demonstrates the consistent succession of each period and testifies to the complex and contradictory evolutionary process of creativity. For most scholars of the poet's work the notion that the evolution of Eliot as a poet was a logical result of the evolution of Eliot as a philosopher and literary critic is important.

As the poet Eliot did not leave the rich literary heritage, he was more prolific in the realm of literary criticism and cultural studies: nearly four hundred articles and essays. In his work "Criticizing the Critic", Eliot, in particular, substantiated his personal belief that the "professional critic is a writer who has not succeeded in the creative field"”, however, his own literary achievements, numerous awards and the recognition of contemporaries and descendants refute this definition. In 1919, Eliot confessed to his former Harvard mentor that there were "only two ways that a writer can become meaningful - to write very much and to publish everywhere or to write very little. This is a matter of temperament. I write very little, I will not become more influential, increasing my production.

\footnotetext{
2 Чертенко А. "И пламя и роза одно" (Вселенные Томаса Стернза Элиота) // Зарубіжна література. - 45 (349) грудень - 2005. - С. 12-24.

3 Элиот Т. С. Избранное. Т. І-ІІ. Религия, культура, литература. - М.:'Российская политическая энциклопедия" (РОССПЭН), 2004. - 752 с. С. 225,
} 
In London, my reputation holds on the small volume of poems published and maintained by two or three poems a year. The only thing that matters is that they must be perfect so that everyone becomes an event" ${ }^{4}$. Indeed, critics or epigones ignored none of Eliot's work. T. Mihed rightly points out that, "From "Prufrock" to "Four Quartets", inclusive, the publication of Eliot's poetry has always become a galvanizing literary event that has attracted considerable attention" 5 . Eliot's works do not only provide aesthetic pleasure (that, in his opinion, is an important function of poetry), but are an example of "elitist aesthetics" as all his poetic achievements designed to tradition as the dynamic unity of human culture. In fact, in the context of rethinking tradition of objective and subjective realities is a key feature of Modernism in general and especially in Eliot's poetics. D. Zatonsky, arguing with the theory of Nathalie Sarraute, who convinced that "the history of literature knows only one tradition - the tradition of combating any tradition", for example, stated, "art is inherent in another equally important and fruitful tradition - the tradition of succession, the tradition of using and modified assimilation of the great classical heritage". Further D. Zatonsky concludes, "Nothing new in the world is born simply from the void, like Aphrodite from the foam of the sea. She rather appears as Athena Pallada - from the head of Zeus”6. As a writer with a philosophical style of thinking, Eliot created his poetic world based on a philosophical interpretation of the entire literary tradition. In articles devoted to the works of Dante, W. Shakespeare, J. Dryden, J. Donn, J. Herbert, E. Marvell, Eliot tried to "bring the poet back to life, which is the great task of criticism". The essay "Homage to John Dryden" (1924) and the "Selected Essays" (1932) became the program at the origin influential critical current, known as the Cambridge School, and later as the "new criticism". In addition, Eliot suggested two important notions for the development of literary and critical thought in scientific discourse. In the article "Hamlet and His Problems" (1919), Eliot was the first to introduce the concept of objective correlative, which meant the harmonization of emotional onset with the objective reproduction of a particular psychological situation, conformity between the feeling and the set of objects, situations, the chain of events that actualize that feeling. In the article "Metaphysical Poets" (1921), Eliot argued that it were

\footnotetext{
${ }^{4}$ Cit. for: Михед Т. Синдром Еліота, або Модерніст проти модернізму // Вікно в світ. Література Великої Британії та Ірландії. - 2001. - № 3. - С. 72-80. С. 79.

${ }^{5}$ Ibid. P. 79.

${ }^{6}$ Затонський Д. В. У пошуках сенсу буття (Погляд на літературу сучасного Заходу). - К.: Дніпро, 1967. -310 с. С. 109.
} 
the poets and metaphysicians of the early seventeenth who "possessed the sensual perception of thought or the transformation of thought into feeling"” . N. Solovyova rightly points out that "the Eliot's correlate is the equivalent of the poetics of masks close to the Elizabethan people, as well as the requirements of suggestiveness offered by French poets of the late nineteenth century"8. The objective correlate became the basis of the neoclassical impersonal theory of poetry, the basic principles of which Eliot outlined in the essay "Tradition and the individual talent" (1919), which argued that "poetry is not a free burst of emotions <...> not an expression of personality, but an escape from it"9 .

Another important term in Eliot's literary-critical discourse is "dissociation of sensibility", which Eliot referred to as a loss of the integrity of "thinking" that characterized (in his point of view) poetry after the seventeenth century. Poetically realizing the demands of S. Baudelaire and G. Flaubert, Eliot demanded from the writers the creative asceticism, the purity of the word, "structurally motivated emotions". This effect, the poet believed, could be achieved through self-irony or "depersonalization", keeping the distance between the source of the image and its final form. In this work, Eliot, in particular, wrote: "The path of the writer to perfection means daily self-sacrifice, loss of individuality" 10 .

It should be emphasized that in order to prepare readers' and critics' perceptions of his own elite texts, Eliot expressed his literary, critical, cultural and religious positions in the essay. Russian researcher A. Astvatsaturov views the poetic theory of Eliot as an auto interpretation of his own poetic creativity. Undoubtedly, there is some sense in these considerations. Although we believe that the opinions of the Eliotologists P. Sloan, K. Brooks, J. Williamson and the domestic researcher S. Pavlychko about the integrity and organic unity of Eliot's poeticcritical work are generally more in line with his intentions - poet, thinker, culturologist, critic and theorist.

In addition, in an essay "From Poe to Valerie" (a lecture read in the Library of Congress on October 19, 1948), Eliot, analyzing E. Poe's essay on the aesthetics of poetry, expressed a view that fully confirms these observations. Given its importance for understanding this issue, let us

\footnotetext{
7 Элиот Т. С. Избранное. Т. І-ІІ. Религия, культура, литература. - М.:’Российская политическая энциклопедия" (РОССПЭН), 2004. - 752 с. С. 553.

8 Зарубежная литература второго тысячелетия. 1000 - 2000: Учеб. пособие / Л.Г. Андреев, Г. К. Косиков, Н.Т. Пахсарьян и др. / Под ред. Л. Г. Андреева. - М.: Высшая школа, 2001. - 335 с. С.334.

9 Элиот Т. С. Традиция и творческая ндивидуальность / Пер. А. Зверева. // Писатели США о литературе. В 2 т. - М.: Прогресс, 1982. - Т. 2 - С. 12-19. С. 19.

${ }^{10}$ Ibid. C. 13.
} 
quote Eliot's utterance in full: "No poet who creates I'art poetique - his theory of poetry - must rely on more than explanation, comprehension, defense, or preparation for his practice, that is, for the creation of his poetry $^{11}$. Moreover, Eliot's theory of poetry has greatly influenced on the development of particular directions in American "new criticism". As a moderate avant-gardist, he became a neoclassical artist in literature (Eliot called himself a "neoclassicist"). Eliot's critics and interpreters of poetry write about the apparent literary reflexivity of his early work, which later acquired all the hallmarks of intertextual strategy. At the same time, researchers often see such a characteristic feature of his creative strategy as a "combination of the incompatible" (W. Scaff). Eliot's critics and interpreters of poetry write about the apparent literary reflexivity of his early poetry, which later acquired all the hallmarks of intertextual strategy. At the same time, researchers often see such a characteristic feature of his creative strategy as a "combination of the incompatible" (W. Scaff). As J. Williamson rightly states, "Eliot began to make it new even before his acquaintance with Ezra Pound"12. All researchers define acquaintance with Ezra Pound as fatal for the poet. Scientists have written a great deal about the creative relationships between Eliot and E. Pound, so, in order not to repeat the known facts, I can testify that these relations ended with the editing of E. Pound's poem "The Waste Land” (1922). Eliot dedicated this poem to E. Pound in the words: For Ezra Pound il migliar fabbro - (Ezra Pound, from the best of masters), probably paying tribute to the role played by the American poet in the author's biography. Eliot, referring to the origins and age-old heritage of the literary tradition of human civilization, sought to expand the "material of poetry" and demonstrate not only theoretically, but also practically the integrity of centuries-old literary process and dialectical unity in the work of the artist of tradition and creative individuality. In "Tradition and the Individual Talent" (1919), he declared the importance of the connection between poetry of a poet and the poetry of other poets and demanded that the artist understand poetry as the living unity of all poetic, all that was created at all times. Following T. E. Hulme and J. Santayana, he created for the intellectual elite. As if reflecting on his vocation, the poet wrote in 1918: "It is necessary to awaken and embarrass the public $<\ldots>$ it is necessary to show that the spiritual level of the nation must constantly grow, otherwise

11 I Элиот Т. С. Традиция и творческая ндивидуальность / Пер. А. Зверева. // Писатели США о литературе. В 2 т. - М.: Прогресс, 1982. - Т. 2 - С. 421.

${ }_{12}$ Williamson G. A Reader Guide to T. S. Eliot: a poem-by-poem analysis. - 1 st Syracuse University Press, 1998. - 248 p. P. 7. 
it will degenerate $<\ldots>$ The power of degeneration is a huge creeping mass, and the power of development is half a dozen people" ${ }^{\text {, }}$. Bearing in mind the obvious complexity caused by the high concentration of relatively small volumes of texts, S. Pavlychko rightly emphasized that his poetry " $<\ldots>$ requires extremely careful and thoughtful reading. Cursory or selective reading can give rise to a mirage of misconceptions about the content and meaning of his creativity. In superficial acquaintance, it is easy to make sure that the poet saw the world as chaos and reflected it in the stream of consciousness, from which the fragments of the subject being emerge from somewhere, and do not notice a persistent search for an idea of what this chaos would subordinate. You can be sure that we are agnostic and do not notice how he wants to define the absolute truth, the universal truth. Finally, one can argue that his poetry is destructive, and not to notice that, by destroying one imperfect philosophy, he creates into another, unfortunately not very perfect"14. In a work on F.G. Bradley, Eliot emphasized that the secret of his (F. G. Bradley's) style was "in an all-consuming commitment to a purely intellectual passion” ${ }^{\prime 15}$. Eliot has a similar intellectual passion, which makes his poetry airtight. The hermetic (“dark style”) of Eliot's poetry is a complexity of artistic language that makes the text difficult to decode adequately. This style attribute is due to the author's idiostyle, in particular the poetically declared elitist aestheticism. Of course, not only modernist or postmodernist texts are hermetic. Even scripture, which is a model of the hermetic literature, initiated the emergence of exegesis. Baroque poets (let us mention at least L. Gongora or J. Marino) practiced "dark style" in their works. For example, L. Gongora wrote: "Dark style awakens the mind". D. Nalyvaiko considers that Gongora "sees in him a peculiar aesthetic factor that stimulates the intellectual activity of the reader, including him in the process of co-creation with the author”16. It is the hermetic style of writing that best meets the requirements of the elitist aesthetics declared by Eliot in his cultural studies and implemented in his poetic practice. For this reason, we propose to consider the genesis of the hermetic sealing of Eliot's works as the product of 1) a synthesis of

\footnotetext{
${ }^{13}$ Cit.for: Красавченко Т. Н. Заметки к определению Т. С. Элиота // Элиот Т. С. Избранное. T. I-II. Религия, культура, литература / Пер. с англ. за ред. А. Н. Дорошевича; составление, послесловие и коментарии Т. Н. Красавченко. - М. РОССПЭН, 2004. - С. 719-741. С. 722. C. 431.

${ }^{14}$ Павличко С. Зарубіжна література. Дослідження та критичні статті. - К.: Основи, 2001. - 431 с.

15 Элиот Т. С. Избранное. Т. І-ІІ. Религия, культура, литература. - М.: «Российская политическая энциклопедия» (РОССПЭН), 2004. - 752 с. С. 691.

${ }^{16}$ Наливайко Д. С. Искусство: направления, течения, стили.- К.: Мистецтво, 1980. - 288 с. С. 132.
} 
artistic and aesthetic reflection, literary interaction, and 2) fragmentation of narrative, which in turn is caused by the complexity of logical and associative connections in the work.

In the format of the interaction study the manifestations as a dynamic reflection of Eliot poems, it is necessary to point out the most important factors that directly or indirectly contributed to their creation. First, it should be emphasized that poetics, focused on reflection and intertextuality, could also cause negative responses, in particular, accusations of eclecticism. Among Western scholars, the poet's bibliographer P. Ackroyd denies the thought of the eclectic nature of Eliot's works. The emergence of these considerations was to some extent initiated not only by an intertextually oriented on the poetic strategy, but also by the apparent fragmentation and cento form of its texts. Moreover, he substantiated his objections with the medium of learning of the poet, which, in fact, became that powerful creative impulse that targeting the search for new ways of poetic self-expression.

Eliot was educated at Harvard, where, in fact, under the influence of the lecturing courses of America's authoritative thinkers, his poetic and philosophical worldview was formed. Among the resonant poetic and theoretical practices of the poet, P. Ackroyd calls lectures by the philologist-classicist G. Marry on the poetry of Homer. It was G. Marry who put forward the idea (which became dominant in Eliot's work) of the literary tradition as a powerful creative impulse that can be countered by individual poetic inspiration. The formation of Eliot's outlook was also greatly influenced by Dante's creativity. Eliot began studying the inheritance of the great Florentine at the turn of the 10-20s of the XX century. Looking for sources for "updating English-language poetry". In this sense, it is significant that both the "New Life" and the "Divine Comedy" at the level of motifs, images, allusions and quotations are interwoven to a greater or lesser extent with each text of Eliot's poetic works. Given the high frequency of use of the texts from these Dante poems, it is possible to classify them as precedents for Eliot's metatext. I. Babbitt played a significant role in shaping the aesthetic dominance of Eliot. All researchers have repeatedly talked about the importance of the influence of Harvard University Professor, literary critic and founder of the "new humanism" in the formation of the future poet.

I. Babbitt's Romanticism contrasted Classicism with his orientation to a single norm and tradition. According to his ideas, the poet should not ignore the past of world literature, but, on the contrary, focus on it, 
apperceive it as eternal and absolute. So the forces of tradition and creative originality have always been in balance". This concept of creative individuality has become dominant in Eliot's poetic practice. The poet also fervently accepted the idea of the literary tradition put forward by I. Babbitt, but he understood the tradition somewhat differently. Eliot formed this understanding under the influence of the philosophy of F. G. Bradley and A. Bergson. According to them, the basis of the literary tradition is the subjective experience of the writer.

Unlike I. Babbitt, who sharply criticized Romanticism and contrasted the romantic world with the classicist, Eliot, in his mature critical works, did not consider Romanticism and Classicism as literary directions in certain mature stages. Classicism was for him a synonym for a literary flawless sample, and Romanticism - a symbol, a term that "describes the state of mind or spirit"17. Confronting the individualism of Romanticism as nothing but limited to the climax of the flaws and contradictions of the Renaissance, and then the Enlightenment, Eliot solves the problem of the individual and humanity other than romantic way. It became possible through the involvement of the creative personality in the cultural tradition, perhaps even deliberately limiting the role of the creative individuality in the cultural process. He believed that such a path to epicism was possible only for a highly conscious creative individual, who was aware of both its uniqueness and its sources, unlike the epic bard, who with the greatest completeness expresses his dissimilarity to the particular society to which he belongs. It is within the course of I. Babbitt that Eliot became acquainted with the works of the French thinker S. Morras, who was a classicist in literature. Eliotologists often quote Eliot's famous credo, from which he later distanced himself, "“Classicist in Literature, Royalist in Politics, and Catholic in Religion”), reiterates S. Morras's demands on the writer. Since there is some confusion in Eliotology, related to this triune poet's credo, we consider it necessary to note, that, firstly, the formulation for the first time appeared in the preface to the book "For Lancelot Andrewes: Essays on Style and Order" (London, Faber, 1928). Interestingly, all the articles have been reprinted many times, including the well-known collection of Selected Essays (N.Y., 1932), but Eliot did not allow itself to republish the book just because of this "unfortunate" phrase in the preface that gave a very simplified picture of his views. Secondly, in a lecture collection read at

${ }^{17}$ Gunner E. T. S. Eliot’s Romantic Dilemma: Tradition's Antitraditional Elements. - N.Y., 1985. P. 21-25. 
the University of Virginia’s “After Strange Gods” (1934), Eliot called the phrase "injudicious". I. Babbitt directed Eliot's thinking to the philosophy of the East. The poet listened to a number of courses on Indian culture. Sights of Indian and Buddhist culture (which he first read in Harvard) can be found in Eliot's works, particularly in "Waste Land" and "Four quartets". In the work "Unity of European Culture", Eliot wrote: "Once upon a time, I studied the ancient languages of India and, although my interests were mostly about philosophy, I also practiced poetry; and I know that my own poetry is impressed by the thoughts and feelings

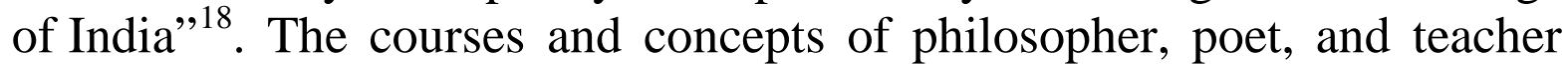
of Harvard J. Santayana had a resonant influence on the future literary theorist and poet. It should be emphasized that the importance of reflecting the philosophy of J. Santayana in the theoretical and practical practice of Eliot, the Eliotologists, unfortunately, have not been sufficiently analyzed, and therefore no definitive conclusions can be drawn. We have nevertheless succeeded in crystallizing the ideas of J. Santayana, which Eliot developed in his writings. Thus, in developing the elitist theory of art, J. Santayana in his book "Reason in Society" wrote: "Culture faces a dilemma: if it is profound and noble, it must remain a culture for the elect; if it is mass, it must become mediocre". We believe that it is J. Santayana's "elitist aesthetics" that has found continuation in Eliot's assessment of poetry as a kind of literature. In "The social purpose of poetry", Eliot formulated the theory according to which the development of culture does not involve the general movement of the masses to a higher cultural level. An analysis of Eliot's seminary papers on philosophy in the framework of the J. Royce course, made by some scholars, suggests that the methodological basis of poetry theory laid at Harvard. In particular, in one of the reports Eliot showed his vision of history interpretation. Eliot tried to answer the question of how to make "the historical past an integral part of the present"19. Six years later, in "Tradition and the Individual Talent", Eliot will reflect on this issue in poetry, in formulating his theory of literary tradition. He interprets it as a sense of history. Eliot believes that "A sense of antiquity is not only a sense of the past, but also a sense of reality. It compels a person to create and feel not only his own generation, but also the whole European culture, beginning with Homer (and within it the literature of his country),

18 Элиот Т. С. Избранное. Т. І-ІІ. Религия, культура, литература. - М.:’Российская политическая энциклопедия" (РОССПЭН), 2004. - 752 с. С. 165.

${ }^{19}$ Jain M. P. T. S. Eliot and American Philosophy. The Harvard Years. - Cambridge UP. Cambridge, 1999. - 135 p. 
as that which exists simultaneously and forms a single continuous series”20. According to Eliot, the poet, referring to the origins of primitive culture, reveals in them the established motives, characteristic of his era. He believed that the eternal, which laid in the past, makes it adequate to the present. The eternal in the literature of the past is what is essential for the subsequent literary eras. In each epoch, it seems to be coming back from the other side, opening the possibilities of the artist not used by his predecessors. Obviously, the development prospects for Eliot had only the era that could accept tradition. Period on turn of the century Eliot saw as a crisis as a leveling of cultural values. Romantic poets, Eliot believed, have sustained the uniqueness of the human "I", thus emphasizing the "originality" of the poet. In his opinion, originality is a fiction, an illusion, since true originality is possible only within the limits of tradition. Having lost touch with the vital beginning, the consciousness becomes fruitless, unable to perceive the literary past as a living organic integrity. Not only in his essays did Eliot argue that tradition for the artist could not be in any way a "pile-up of ruins", a literary tradition projected his entire poetic inheritance. As T. Krasavchenko rightly points out, "in essence, all or almost all of what Eliot did in poetry and criticism was because he was the representative of avant-garde American culture in traditional, English culture"21. Famous domestic Americanist Denisova in her work "Traditionalism for salvation. Notes on the cultural studies of T. S. Eliot" wrote: "The theme of tradition in the poetry of T. S. Eliot is inexhaustible. The poet is creative to her, the idea of tradition is important to him, through which the continuity of culture - the only immutable reality of man, homosapiens - is carried out. This became the basis of T. S. Eliot's cultural studies" 22 . The researcher goes on to say: "Relation with the cultural tradition $<\ldots .>$, thus, for Eliot is an indispensable attribute of poetry, it can be seen as a kind of vertical ethics, that is, the involvement of creative individuality in the human community, and its most rich and productive directed to the infinite component"23. P. Ackroyd notes that one of the significant factors in Eliot's work was his acquaintance with A. Simons's book “The Symbolist Movement

20 Элиот Т. С. Традиция и творческая ндивидуальность / Пер. А. Зверева. // Писатели США о литературе. В 2 т. - М.: Прогресс, 1982. - Т. 2 - С. 12-19. С. 13.

${ }^{21}$ Красавченко Т. Н. Заметки к определению Т. С. Элиота // Элиот Т. С. Избранное. Т. І-II. Религия, культура, литература / Пер. с англ. за ред. А.Н. Дорошевича; составление, послесловие и коментарии Т. Н. Красавченко. - М. РОССПЭН, 2004. - С. 719-741.

${ }^{22}$ Денисова Т. Н. Традиционализм во спасение. Заметки о культурологии Т. С. Элиота // Американский характер. Очерки культуры США. Традиция в культуре. - М.: Наука, 1998. - С. 166-178. С. 167.

${ }^{23}$ Ibid. P. 174. 
in Literature" (1899). Familiarity with this book influenced the further creative pursuits of T.S. Eliot. This work was at that time the most authoritative study in the field of French poetry. The A. Simons interpretation of Symbolism showed Eliot how a contemporary writer (such as the poetry of Jean Paul, Arthur Rambo, Paul Verlaine and Jules Laforgue) could ironically distance himself from the romantic worldview, and revive in the artistic poetry world not stereotypical but individual emotion. Only individual emotion, according to Eliot, is the organic unity of thought and feeling. Thus, having received a fine philological education in the leading universities of America and Europe, Eliot began, or, more precisely, continued his creative career with the formed cultural views and clear preferences, which further enabled his cooperation with the imagists. Using the following atlas of the texts found in Eliot's poetic works, we could say that the intertextual framework of his metatext is quite impressive. As there are many authors who have been approached by the poet throughout his work, I find it inappropriate to classify them by periods of poetic evolution. For this reason, we have chosen a type of classification based on the frequency of borrowing of quotations, paraphrases, allusions and reminiscences (we did not use motive and imaginative interaction here), in particular, precedent and peripheral. Thus, the precedent authors and works include the Bible (more than 30 ), W. Shakespeare (23), Dante (13), Ovid's Metamorphoses, as well as studies in the anthropology of J. Fraser and J. Weston. Peripheral authors and works: Upanishad, Bhagavad-Gita, Blessed Augustine, Buddha, Hesiod, Aeschylus, Heraclitus, Sophocles, Virgil, Seneca, G. Cavalcanti, J. Chaucer, E. Spencer, L. Andrews, T. Kid, J. Donn, B. Johnson, T. Middleton, E. Marvel, O. Goldsmith, W. Blake, J. de Nerval, A. Tennyson, R. Wagner, C. Baudelaire, G. Adams, and P. Verlaine.

Of course, I cannot claim that the list of authors and proto-texts in Eliot's poetry is complete. However, it demonstrates the elitism of the level of aesthetic patterns and the encyclopedic knowledge of Eliot. As mentioned, Eliot, having received excellent philological and philosophical education at Harvard, Sorbonne and Oxford, began to create his poetic world, using literary reflection.

\section{SUMMARY}

The article deals with the sense of tradition as the dominant source of intertextuality. T. S. Eliot creativity marked an entire era in the history of world literature of the twentieth century. Poet's intense reflection of the tragedy of human existence, human alienation, degradation of society 
is embodied in the complicated art form, a kind of figurative and symbolic system, conditional associative principles of poetics. Eliot's poetry was partly characterized as sealed, coded, devoid of clarity and unambiguous comprehension. The various "keys" used in this decoding process formed the extremely broad and multifaceted interpretive context of Eliot's work. For the poet himself, explaining the essence of innovation lays primarily in the plane of tradition. Stressing the need to find an artistic form adequate to the modern world, the poet pointed out that it is possible to create only taking into account the experience of previous cultural epochs. Tradition has become the benchmark and foundation of the artist's creativity. Therefore, an adequate perception of Eliot's poetry is possible only if we investigates how it reflected and transformed the images, motives, poetic features of those authors who most respected and contributed to the formation of his original artistic world. The colossal diversity of the source material forms the exceptionally rich intertextual field of Eliot's poetry, at the same time making intertextuality one of its dominant features.

\section{REFERENCES}

1. Graham Allen, "Intertextuality" in The Literary Encyclopedia, http://www.paulj.myzen.co.uk/blog/teaching/reinventions/files/2009/07/ Allen-Intertextuality.pdf Date of access at 27/8/2019.

2. Gunner E. T. S. Eliot's Romantic Dilemma: Tradition's Antitraditional Elements. - N.Y., 1985. - P. 21-25.

3. Jain M. P. T. S. Eliot and American Philosophy. The Harvard Years. - Cambridge UP. Cambridge, 1999. - 135 p.

4. Williamson G. A Reader Guide to T. S. Eliot: a poem-by-poem analysis. -1 st Syracuse University Press, 1998. - 248 p. P. 7.

5. Денисова Т. Н. Традиционализм во спасение. Заметки о культурологии Т. С. Элиота // Американский характер. Очерки культуры США. Традиция в культуре. - М.: Наука, 1998. - С. 166-178. С. 167.

6. Зарубежная литература второго тысячелетия. 1000 - 2000: Учеб. пособие / Л.Г. Андреев, Г. К. Косиков, Н.Т. Пахсарьян и др. / Под ред. Л. Г. Андреева. - М.: Высшая школа, 2001. - 335 с. С. 334.

7. Затонський Д. В. У пошуках сенсу буття (Погляд на літературу сучасного Заходу). - К.: Дніпро, 1967. - 310 с. С. 109.

8. Красавченко Т. Н. Заметки к определению Т. С. Элиота // Элиот Т. С. Избранное. Т. I-II. Религия, культура, литература / Пер. с англ. за ред. А. Н. Дорошевича; составление, послесловие 
и коментарии Т. Н. Красавченко. - М. РОССПЭН, 2004. - С. 719-741. С. 722 .

9. Михед Т. Синдром Еліота, або Модерніст проти модернізму // Вікно в світ. Література Великої Британії та Ірландії. - 2001. - № 3. С. $72-80$. С. 79.

10. Наливайко Д. С. Искусство: направления, течения, стили.К.: Мистецтво, 1980. - 288 с. С. 132.

11. Павличко С. Зарубіжна література. Дослідження та критичні статті. - К.: Основи, 2001. - 431 с. С. 431.

12. Чертенко А. «И пламя и роза одно» (Вселенные Томаса Стернза Элиота) // Зарубіжна література. - 45 (349) грудень - 2005. C. 12-24.

13. Элиот Т. С. Избранное. Т. I-II. Религия, культура, литература. - М.: «Российская политическая энциклопедия» (РОССПЭН), 2004. $752 \mathrm{c}$.

14. Элиот Т. С. Традиция и творческая ндивидуальность / Пер. А. Зверева. // Писатели США о литературе. В 2 т. - М.: Прогресс, 1982. - T. 2 - C. 12-19. C. 19.

\section{Information about the author: Statkevych L. P.,}

Candidate of Philological Sciences, Associate Professor, Foreign Philology Department, Academic and Scientific Institute of Philology and Journalism, V. I. Vernadsky Taurida National University 33, John McCain str., Kyiv, 01042, Ukraine 